Vietnam Journal of Mechanics, VAST, Vol.30, No. 1 (2008), pp. 43-54

\title{
COMPARISON OF TWO HYDROLOGICAL MODEL SIMULATIONS USING NAM AND XINANJIANG FOR NONG SON CATCHMENT
}

\author{
Vu Van Nghi ${ }^{1}$ \\ State Key Laboratory of Hydrology, \\ Water Resources and Hydraulic Engineering, \\ Hohai University, no. 1 Xikang Road, Nanjing 210098, China \\ Dang Thanh Lam, Do Duc Dung \\ Southern Institute for Water Resources Planning, \\ 271/3 An Duong Vuong Street, District 5, \\ Ho Chi Minh City, Vietnam
}

\begin{abstract}
The study presents the hydrological simulations for the Nong Son catchment, a drainage area of the Vu Gia-Thu Bon basin in the Central Vietnam, by using the NAM and XINANJIANG models. Simulation results for both models show good agreement between calculated and observed discharges at the stream gauge. The overall water balance error is less than $\pm 10 \%$, Nash-Sutcliffe efficiency $R^{2}$ above 0.85 , and Pearson correlation coefficient $r$ above 0.92 in both model calibration and verification period. Although NAM's performance shows a slightly better correspondence between the discharges at the stream gauge, the XINANJIANG model shows a relatively better reproduction of the runoff components (i.e. overland flow, interflow and baseflow).

Keywords: Conceptual model, NAM, XINANJIANG, model simulation, model comparison
\end{abstract}

\section{INTRODUCTION}

In recent years, many water resource studies related to flood control, irrigation, hydropower, domestic and industrial uses have increased enormously. In those studies, hydrological simulation models are often used to provide the missing information as a basis for decisions regarding the development and management of water and land resources.

Traditionally, hydrological simulation modeling systems are classified into three main groups, namely, (1) empirical black box, (2) conceptual, and (3) distributed physically based systems. The great majority of modeling systems used in practice belongs to type (2) and require a modest numbers of parameters (5-10). Despite their simplicity, many models have proven quite successful in reproducing flows close to measured records. However, there is no universal model which is appropriate for the solution of all hydrological problems as well as for all catchments with different natural conditions; thus the choice of model to be used by the applied hydrologist in any given situation becomes a onerous task.

\footnotetext{
${ }^{1}$ Corresponding author:

Email: vuvannghi@yahoo.com Tel: 0086.15850569677
} 
The water resource in the Nong Son catchment, an upper area of Vu Gia-Thu Bon basin, has been studied for basis of development. As a result, the objective of the present study is to access the suitability of two popular watershed scale hydrological models NAM (see [2]) and XINANJIANG (see [16]) to simulate the hydrology of this study area. The paper presents the results of hydrological simulations and comparative performances of NAM and XINANJIANG for the Nong Son catchment in two periods, model calibration from 1980 to 1985 and model validation from 1986 to 1990.

\section{MATERIALS AND METHODS}

\subsection{Description of the Models}

NAM is a traditional hydrological modeling system of the lumped conceptual type operating by continuously accounting for the moisture contents in four mutually interrelated storages. NAM was originally developed at the Technical University of Denmark (see [7]) and has been modified and extensively applied by Danish Hydraulic Institute (DHI) in a large number of engineering projects covering all climatic regimes of the world. Furthermore, NAM has been transferred to more than 100 other organizations worldwide as part of DHI's MIKE 11 generalized river modeling package (see [2]). The structure of NAM is illustrated in Fig. 1. NAM has in its present version a total of 17 parameters; however, in most cases only about 10 of these as indicated in Table 2 are adjusted during calibration.
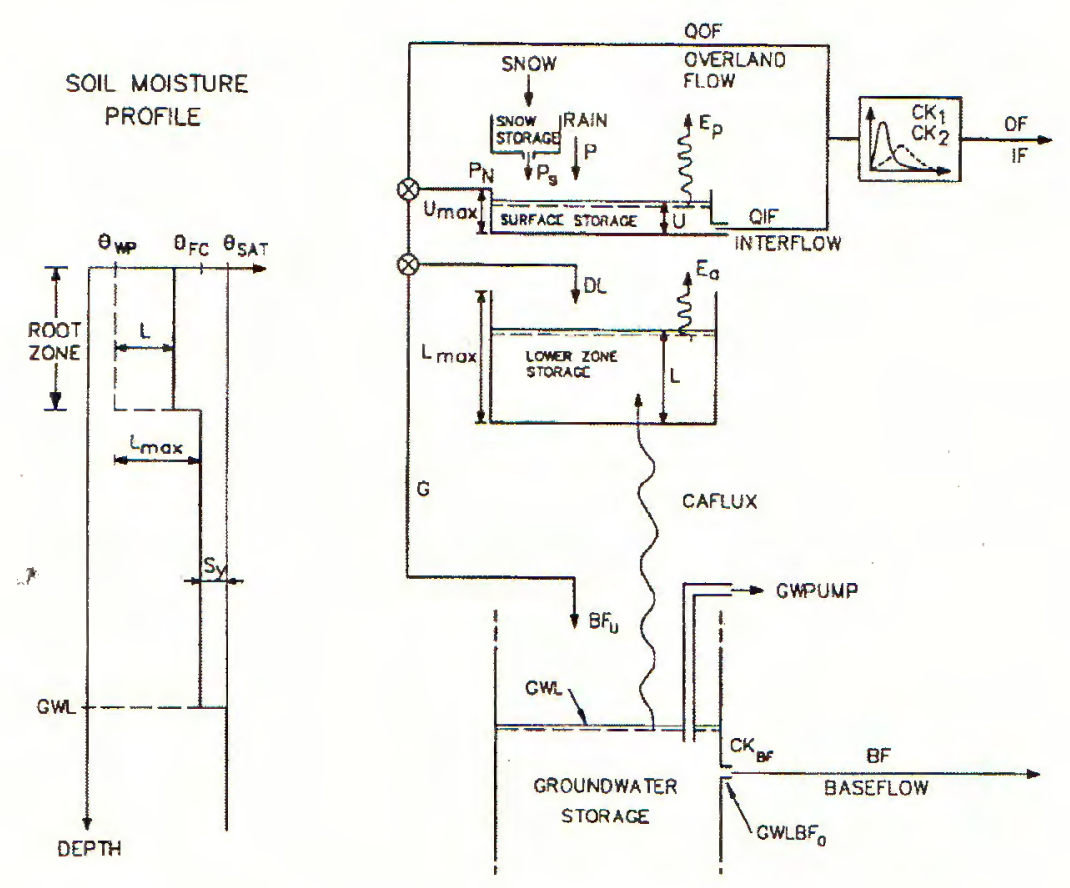

Fig. 1. Structure of the NAM model (see [2])

In Fig. 1, main model parameters such as $U_{\max }, L_{\max }, C K_{1,2}$ and $C K_{B F}$ are described in Table 2, $U$ is the amount of water in the surface storage $(\mathrm{mm}), P_{N}$ is the excess water 
(mm. $\left.\mathrm{d}^{-1}\right), E_{p}$ is the potential evapotranspiration rate $\left(\mathrm{mm} \cdot \mathrm{d}^{-1}\right), D L$ is the amount of water diverted as infiltration into the lower zone $\left(\mathrm{mm}^{-1} \mathrm{~d}^{-1}\right), E_{a}$ is the actual evapotranspiration rate $\left(\mathrm{mm} \cdot \mathrm{d}^{-1}\right), G\left(B F_{u}\right)$ is the groundwater recharge $\left(\mathrm{mm} \cdot \mathrm{d}^{-1}\right), C A F L U X$ is the capillary flux $\left(\mathrm{mm} \cdot \mathrm{d}^{-1}\right)$, GWPUMP is the net groundwater abstraction $\left(\mathrm{mm} \cdot \mathrm{d}^{-1}\right), S_{y}$ is the specific yield of reservoir, GWL is the groundwater table depth $(\mathrm{mm}), G W L B F_{0}$ is the maximum groundwater table depth $(\mathrm{mm}), \theta_{W P}, \theta_{F C}, \theta_{S A T}$ are the moisture contents at wilting point, field capacity and saturation $(\mathrm{mm})$, respectively.

The XINANJIANG model, a conceptual model as well, was developed in 1973 and published in 1980 (see [15]). It has been used widely and successfully in China. Its main feature is the concept of runoff formation on repletion of storage, which means that runoff is not produced until the soil moisture content of the aeration zone reaches field capacity, and thereafter runoff equals the rainfall excess without further loss. Since the study area belongs to the semiarid region where both Horton and Dunne runoffs coexist, a new runoff parameterization scheme developed by Hu (see [4]) was added to the original XINANJIANG model, which dynamically represents both Dunne and Horton runoff generation mechanisms. In the structure of XINANJIANG (Fig. 2), the basin is divided into a set of sub-basins. The outflow from each subbasin is first simulated and then routed down the channels to the main basin outlet. The inputs to the model

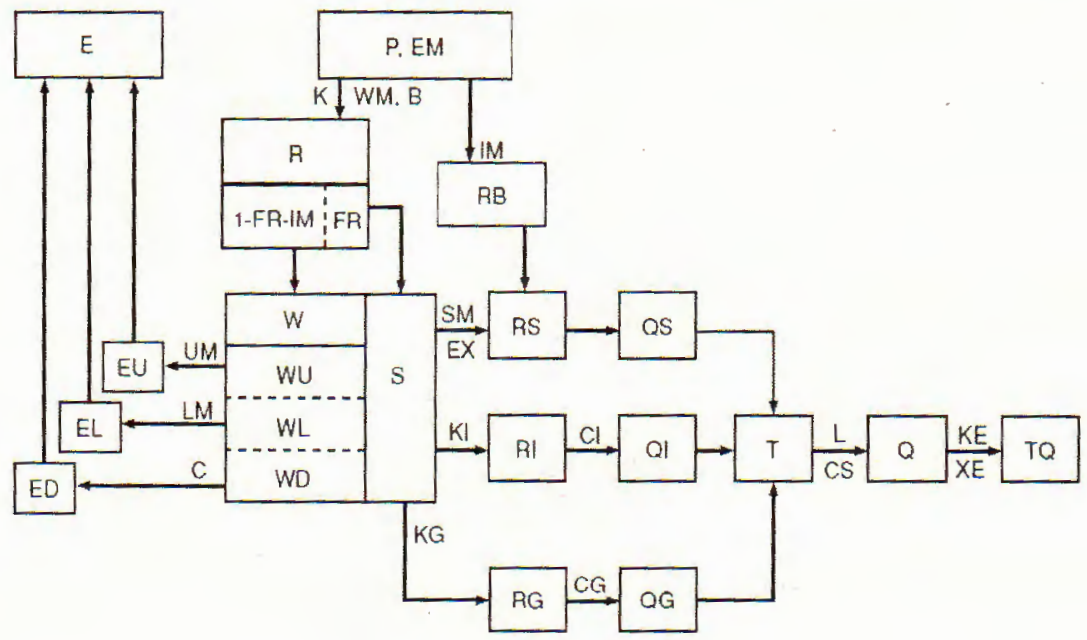

Fig. 2. Flow chart for the XINANJIANG model (see [16])

are areal mean rainfall, $P$, and measured pan evaporation, EM. The outputs are the discharge, $T Q$, from the whole basin and the actual evapotranspiration, $E$, which includes three components $E U, E L$ and $E D$. The state variables are the areal mean tension water storage, $W$, and the areal mean free water storage, $S$. The areal mean tension water $W$ has three components $W U, W L$, and $W D$ in the upper, lower and deep layer, respectively. The $F R$ is runoff contributing arca factor which is related to $W$. The rest of the symbols inside the blocks are all internal variables. $R B$ is the runoff directly from the small portion of impervious area. $R$ is the runoff produced from the pervious area and divided into three components $R S, R I$, and $R G$ referred to as surface runoff, interflow and groundwater runoff, respectively. The three components are further transferred into $Q S, Q I$, and $Q G$ 
and together form the total inflow to the channel network of the sub-basin. The outflow of the sub-basin is $Q$.

The characters outside the blocks denote parameters. $K$ is the ratio of potential evapotranspiration to pan evaporation if pan evaporation measurements are used as references. $W M$ and $B$ are two parameters describing the tension water distribution. $W M$ is the areal mean tension water capacity having components $U M, L M$ and $D M . B$ is the exponent of the tension water capacity distribution curve. $I M$ is the factor of impervious area. $S M$ and $E X$ are similar to $W M$ and $B$ while they describe the free water capacity distribution. $K I$ and $K G$ are coefficients relating to $R I$ and $R G$. CI, CG,L,CS, KE and XE are parameters for flow routing. In summary, there are 17 parameters when using lag and route method for sub-basin's and Muskingum method for main basin's flow routing, among which 15 parameters are for the sub-basin. Generally, the output is more sensitive to 7 parameters, namely, $K, S M, K G, K I, C G, C S$ and $L$.

\subsection{Watershed Description}

The study area $\left(14^{\circ} 41^{\prime}-15^{\circ} 45^{\prime} \mathrm{N}\right.$ and $\left.107^{\circ} 40^{\prime}-108^{\circ} 20^{\prime} \mathrm{E}\right)$ covers $3,160 \mathrm{~km}^{2}$ with the gauging station at Nong Son. It is a mountainous sub-basin of the Vu Gia-Thu Bon basin located in the East of Truong Son mountain range, the center of Vietnam (Fig. 3). The altitude ranges from several meters to 2,550 meters above sea level (data derived from DEM $90 \times 90$ ). The mean slope and the river network density of the basin are $24.2 \%$ and $0.41 \mathrm{~km} / \mathrm{km}^{2}$ respectively. The main soil in the basin is granite, alluvial soil, i.e. iron pan, grandiosity, deposit alluvia, clay and sand.

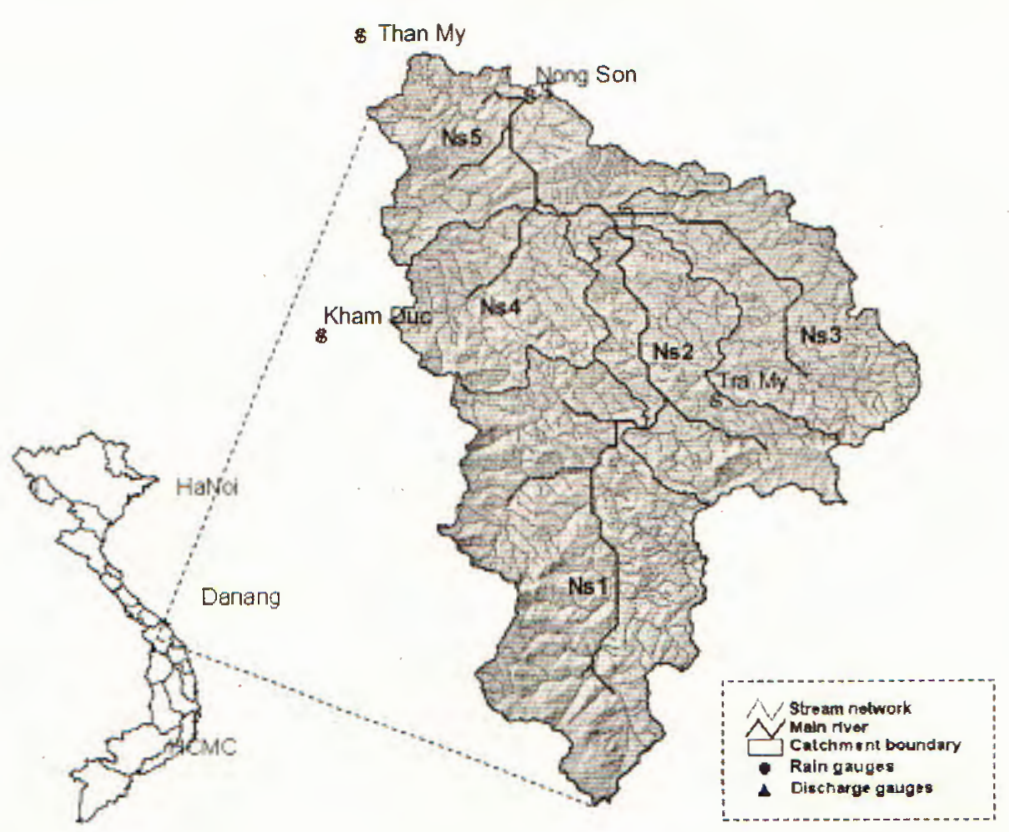

Fig. 3. Location of the Nong Son Catchment with the gauging sites and subbasins

In this study area, there are only four rain gauges in which only one gauge collects hourly data, one climatic station at Tra $\mathrm{My}$, and one discharge gauge at Nong Son. In 
general, the hydro-meteorological station network is sparce, i.e. a rain gauge is installed every $800 \mathrm{~km}^{2}$. The data have been provided by the Hydro-Meteorological Data Center (HMDC), the Ministry of Natural Resources and Environment (MONRE) of Vietnam.

Due to the effects of predominating wind direction (North-East in the rainy season) and topography, rainfall in the basin is very high and significantly varies in space and time. According to the rainfall records from 1980 to 2004, the rainfall distribution spatially increases from East to West and from North to South (the mean annual rainfall at Tra My is more than 4,000 $\mathrm{mm}$ whereas at Thanh My just more than 2,200 $\mathrm{mm}$ ).

For seasonal rainfall distribution, the rainfall in October and November reaches up to $1,800 \mathrm{~mm}$. The period of the North-East wind lasts from September to December coinciding with the rainy season. Although the rainy season lasts 4 mouths, rainfall $70 \%$ of annual rainfall. Furthermore, the annual rainfall amounts averages show yearly variations from $2,417 \mathrm{~mm}$ (1982) to $6,259 \mathrm{~mm}$ (1996) with an average value of $3,697 \mathrm{~mm}$. The annual runoff coefficient (runoff/precipitation) in this period varies intensively between $0.49(1982)$ and 0.81 (1995) with an average value of 0.73.

\subsection{Data processing}

NAM and XINANJIANG models were calibrated at the watershed outlet using daily and monthly measured data during 1980 through 1985. Field data from 1986 to 1990, were used for model validation.

As described above, NAM, a lumped conceptual model, considers the entire catchment as one unit while XINANJIANG divides the basin into a set of sub-basins subbasins. Hence, for this case, the Nong Son catchment was delineated into 5, called Ns1-Ns5 (Fig. 3) by using the catchment delineation tool in MIKE Basin (see [3]). The characteristics of the subbasins are shown in Table 1 .

Table 1. Area and flow length of subbasins of the Nong Son catchnent

\begin{tabular}{|l|c|c|c|c|c|}
\hline Characteristics & Ns1 & Ns2 & Ns3 & Ns4 & Ns5 \\
\hline Area $\left(\mathrm{km}^{2}\right)$ & 1,107 & 536 & 567 & 425 & 525 \\
\hline Length $(\mathrm{m})$ & 57,895 & 30,263 & 29,950 & 20,500 & 10,000 \\
\hline
\end{tabular}

The daily rainfall data were collected from 4 stations and processed into areal rainfall for subwatersheds and watershed levels using the Theissen polygon.

There is only one climatic station observing evaporation by Piche tube at Tra My in the basin. However, the observed piche data often show erroneous results which are difficult to explain (see [6]). On the other hand, potential evapotranspiration is an input data requirement for both NAM and XINANJIANG (pan evaporation can be used for XINANJIANG). Therefore, the potential evapotranspiration data that are estimated by the PenmanMonteith method (see [1]) according to monthly meteorological data such as mean temperature, relative humidity, air pressure (optional), sunshine hour, and wind speed; land cover data (http://www.geog.umd.edu/landcover $/ 1 \mathrm{~km}$-map.html) and vegetation-related parameters based on AVHRR (Advanced Very High Resolution Radiometer) and LDAS (Land Data Assimilation System) information (http://www.ce.washington.edu /pub/HYDRO/cherkaue/VIC-NL/Veg/veg_lib) were used for model development. 


\subsection{Performance evaluation measures}

Several statistical measures can be used to qualify the differences in the predicted and observed state variables, and evaluate the performance of a model (see [5], [13], [14]). In this study, the following three statistical measures were used to measure the quality and reliability of NAM and XINANJIANG predictions of the discharge from the Nong Son catchment:

Coefficient of mass residual:

$$
B I A S=\frac{\sum_{i=1}^{N} O_{i}-\sum_{i=1}^{N} P_{i}}{\sum_{i=1}^{N} O_{i}} .
$$

Nash-Sutcliffe efficiency:

$$
R^{2}=\frac{\sum_{i=1}^{N}\left(O_{i}-O\right)^{2}-\sum_{i=1}^{N}\left(P_{i}-O_{i}\right)^{2}}{\sum_{i=1}^{N}\left(O_{i}-O\right)^{2}} .
$$

Pearson correlation coefficient:

$$
r=\frac{\sum_{i=1}^{N}\left(P_{i}-P\right)\left(O_{i}-O\right)}{\sqrt{\sum_{i=1}^{N}\left(P_{i}-p\right)^{2}} \sqrt{\sum_{i=1}^{N}\left(O_{i}-O\right)^{2}}}
$$

where $N$ is the total number of the observations, $O_{i}$ is $i^{t h}$ observation, $P_{i}$ the predicted value of the $i^{\text {th }}$ observation, and $O$ and $P$ respectively the mean of observed and predicted values $(i=1$ to $N)$.

In addition to these statistical measures, the reliability of model outputs is judged through the graphical presentations of the predicted and observed values.

\section{RESULTS AND DISCUSSION}

The calibration procedures are found by "trial and error". The numerical and graphical performance criteria described in Section 2.4 were used as important guidance for hydrologists when deciding what set of parameter values they assessed to be optimal. As these decisions inevitably depend on the personal experiences and judgments of hydrologists, it may be argued that this procedure adds an undesirable degree of subjectivity to the results. However, given the large number of performance criteria and the large number of adjustable parameters no suitable and well-proven automatic parameter optimization techniques exist. Applying standard calibration procedures in which hydrologists had comprehensive experience, the results may be seen as typical different modeling systems, calculated using standard engineering procedures for data collection and model construction.

Model simulation was calibrated on the basis of the data in 6 years (1980-1985 with the mean annual runoff of $2,522 \mathrm{~mm}$ ) and validated in subsequent 5 years (1986-1990 with the mean annual runoff of $2,400 \mathrm{~mm}$ ). The summaries of calibration parameters 
for NAM and XINANJIANG are given in Table 2 and 3, respectively. The results of the model calibration and validation are summarized in Table 4, which shows the overall water balances (Bias), $R^{2}$ and $r$ numerical criteria. The simulated and observed daily hydrographs are shown in Fig. 5 and 6 . The annual water balances during the calibration and validation period are shown in Fig. "4. The simulation results are discussed in following paragraph.

The NAM model has been applied successfully in Vietnam for the several areas at Sai Gon-Dong Nai basin (see [8], [9]), Tay Nguyen (see [10]) and Vu Gia-Thu Bon basin (see [11]), etc. The NAM calibration for the Nong Son catchment was executed. The calibration parameters for the Nong Son catchment in Table 2 are considered to be optimal and suitable showing good agreement between simulated and observed discharges.

For the XINANJIANG model, this is the first time to apply it to a catchment in Vietnam, so that cautiousness in the calibration was considered to get the optimal set of model parameters for the Nong Son catchment where natural conditions are too different with that in China, especially the climate, e.g. the mean annual rainfall in the Nong Son catchment is approximately $3,700 \mathrm{~mm}$ while $<1,000 \mathrm{~mm}$ in almost catchments where this model have been applied successfully, moreover the rainfall intensity in this study area is very high causing many extreme floods (see [12]) unlike in China. The calibrated parameter values are as shown in Table 3.

Table 2. NAM model parameter values from the manual calibration in the 19801985 period

\begin{tabular}{|l|c|}
\hline Calibration model parameter & Value \\
\hline Maximum water content in surface storage, $U_{\max }[\mathrm{mm}]$ & 10 \\
\hline Maximum water content in root zone storage, $L_{\max }[\mathrm{mm}]$ & 150 \\
\hline Overland flow runoff coefficient, $C Q O F$ & 0.605 \\
\hline Time constant for interflow, $C K_{I F}[$ hours] & 377 \\
\hline Time constant for routing interflow and overland flow, $C K_{1,2}[$ hours] & 29 \\
\hline Root zone threshold value for overland flow, $T_{O F}$ & 0.491 \\
\hline Root zone threshold value for interflow, $T_{I F}$ & 0.093 \\
\hline Root zone threshold value for groundwater recharge, $T_{G}$ & 0.003 \\
\hline Baseflow time constant $C K_{B F}$ [hours] & 1,104 \\
\hline
\end{tabular}

Calibration and validation periods consist of dry, average and wet years. Analysis of Bias for both the calibration and validation periods shows a contrast. One reason for this different behavior lies in the different hydro-climatic conditions of the calibration and validation periods. Compared to the calibration period, validation period precipitation decreases by $450 \mathrm{~mm} / \mathrm{a}$ while potential evapotranspiration and discharge decrease by 16 $\mathrm{mm} / \mathrm{a}$ and $123 \mathrm{~mm} / \mathrm{a}$ respectively. Never the less Bias in these periods is less than $\pm 10 \%$. Overall analyses are given in Table 4 for the calibration and validation periods; the resuits show a similar trend. This is indicative of the models' stability as applied to the Nong Son catchment.

During the calibration period, the relative volume error between observed and simulated average annual discharges, except in 1982, varied from $4.7 \%$ to $-5.3 \%$ with an overall value of $-3.0 \%$ for XINANJIANG and from $2.7 \%$ to $-6.0 \%$ with an overall value of $-4.1 \%$ for 
Table 3. XINANJIANG model parameter values from the manual calibration in the 1980-1985 period

\begin{tabular}{|l|c|}
\hline Parameters & Values \\
\hline The ratio of potential evapotranspiration to pan evaporation, $K$ & 1 \\
\hline The areal mean tension water capacity of upper part, $U M[\mathrm{~mm}]$ & 25 \\
\hline The areal mean tension water capacity of lower part, $L M[\mathrm{~mm}]$ & 90 \\
\hline The areal mean tension water capacity of deeper part, $D M[\mathrm{~mm}]$ & 30 \\
\hline The coefficient of deep evapotranspiration, $C$ & 0.4 \\
\hline The exponent of the tension water capacity distribution curve, $B$ & 0.4 \\
\hline The factor of impervious area, IM & 0.1 \\
\hline The areal mean free water capacity, $S M[\mathrm{~mm}]$ & 80 \\
\hline The exponent of the free water capacity distribution curve, $E X$ & 1.5 \\
\hline The outflow coefficient of free water to interflow, $K I$ & 0.5 \\
\hline The outflow coefficient of free water to groundwater, $K G$ & 0.3 \\
\hline The recession constant of interflow storage, $C I$ & 0.9 \\
\hline The recession constant of groundwater storage, $C G$ & 0.99 \\
\hline The storage constant of Muskingum method, $K E[$ hours] & 14 \\
\hline The weighting factor of Muskingum method, $X E$ & 0.0 \\
\hline
\end{tabular}

Table 4. Performance statistics of two models NAM and XINANJIANG during calibration (1980-1985) and validation (1986-1990) periods for the Nong Son catchment

\begin{tabular}{|l|c|c|c|}
\hline Performance statistics & Period & NAM & XINANJIANG \\
\hline \multirow{2}{*}{ Bias $(\%)$} & Calibration & -4.100 & -3.035 \\
\cline { 2 - 4 } & Validation & 9.300 & 9.735 \\
\hline \multirow{2}{*}{ Nash-Sutcliffe efficiency $\left(R^{2}\right)$} & Calibration & 0.900 & 0.889 \\
\cline { 2 - 4 } & Validation & 0.860 & 0.853 \\
\hline \multirow{2}{*}{ Pearson correlation coefficient $(r)$} & Calibration & 0.949 & 0.943 \\
\cline { 2 - 4 } & Validation & 0.931 & 0.927 \\
\hline
\end{tabular}

NAM. In the year 1982, both models over-simulated the annual streamflow, i.e. - $46.1 \%$ for NAM and $-45.1 \%$ for XINANJIANG. This poor simulation could be due to the fact that the year 1982 is considered as the dry year, hence water abstraction for irrigation and other uses caused the discharge to be far less. Nevertheless, exact reasons and investigation information are not known. Contrary to the calibration period, in the validation period NAM under-simulated ( $-1.6 \%$ to $17.4 \%$ with an overall value of $9.3 \%)$ and XINANJIANG under-simulated $(1.6 \%$ to $16.0 \%$ with an overall value of $9.7 \%)$ the streamflow. These statistics indicate that the calibrated NAM and XINANJIANG models can simulate the annual average flows satisfactorily for periods outside the calibration period. Actually, in comparative performance terms, it is very difficult to say which model is better in this case. However, for the other performance statistics given in Table 4, NAM performance was slightly better than XINANJIANG, i.e. the model efficiency and correlation coefficient during the calibration period are 0.900 and 0.949 for NAM companded 0.889 and 0.943 for XINANJIANG. Moreover during the validation period, these criteria consolidate although 
their values are smaller with $R^{2}=0.860$ and $r=0.931$ for NAM against $R^{2}=0.853$ and $r=0.927$ for XINANJIANG. In general, both NAM and XINANJIANG performances show "very good" fit in simulating streamflow hydrographs for the Nong Son catchment. The visual comparison of observed against NAM's and XINANJIANG's simulated daily streamflow timeseries during 1980-1985 (Fig. 5) and during 1986-1990 (Fig. 6) also show that shape and timings of the observed and simulated hydrographs agree for the most part of the two periods.
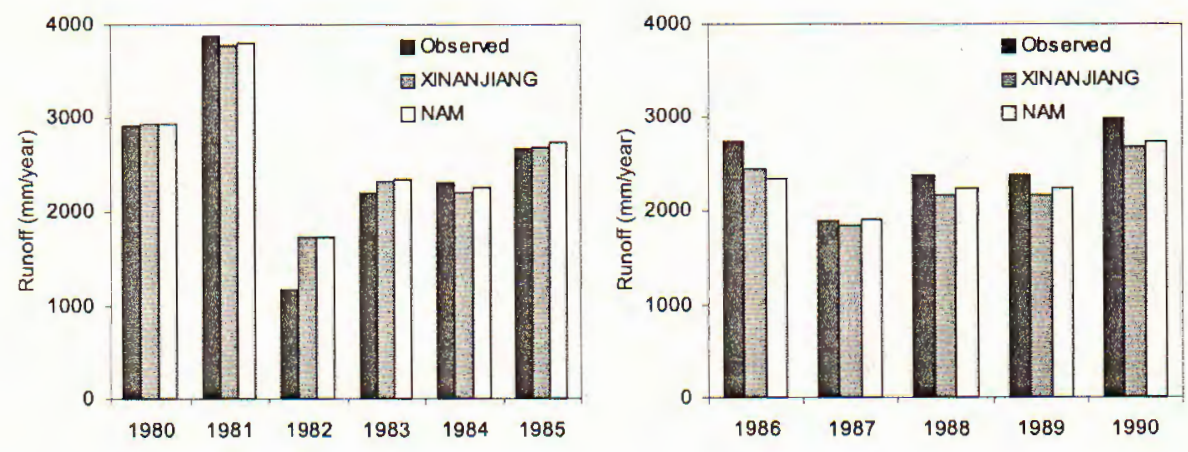

Fig. 4. Annual water balances of NAM and XINANJIANG during calibration (1980-1985) and validation (1986-1990) periods for the Nong Son catchment
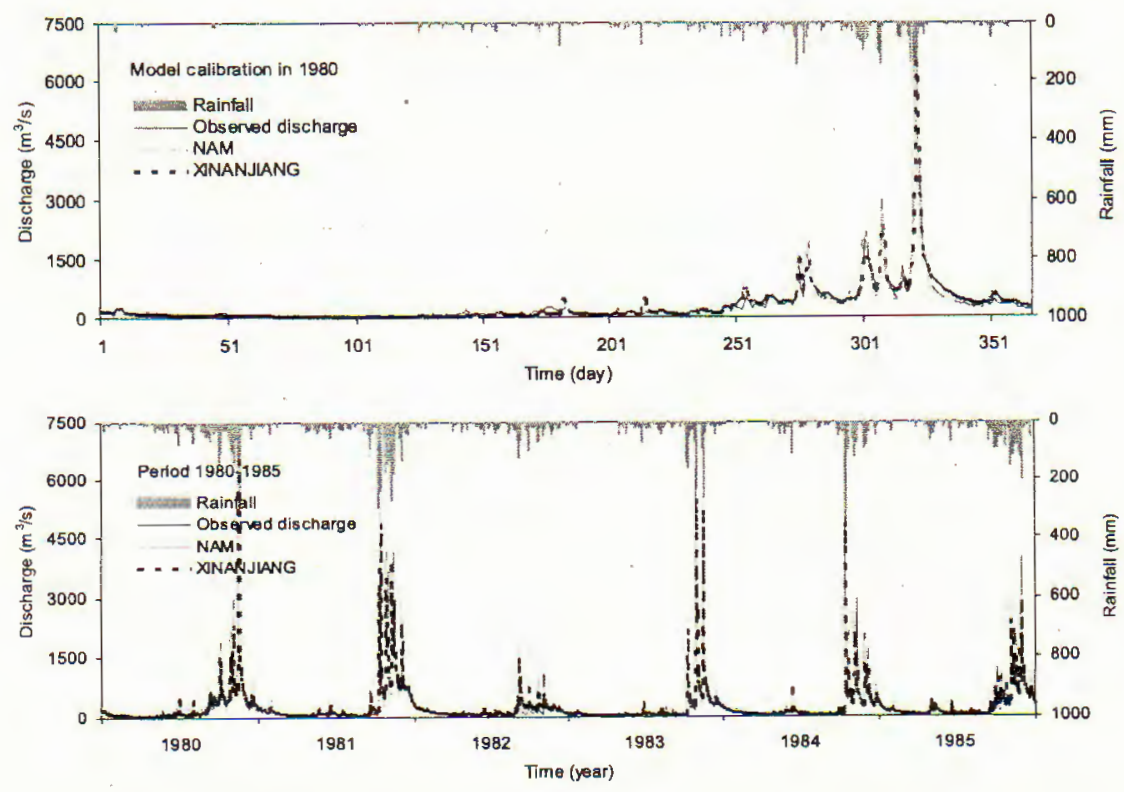

Fig. 5. Model calibration results of daily discharges at Nong Son in the 1980-1985 period

In terms of flow separation, the overall performances of both NAM and XINANJIANG as they apply to the Nong Son catchment are very satisfactory. Portions of overland flow, 

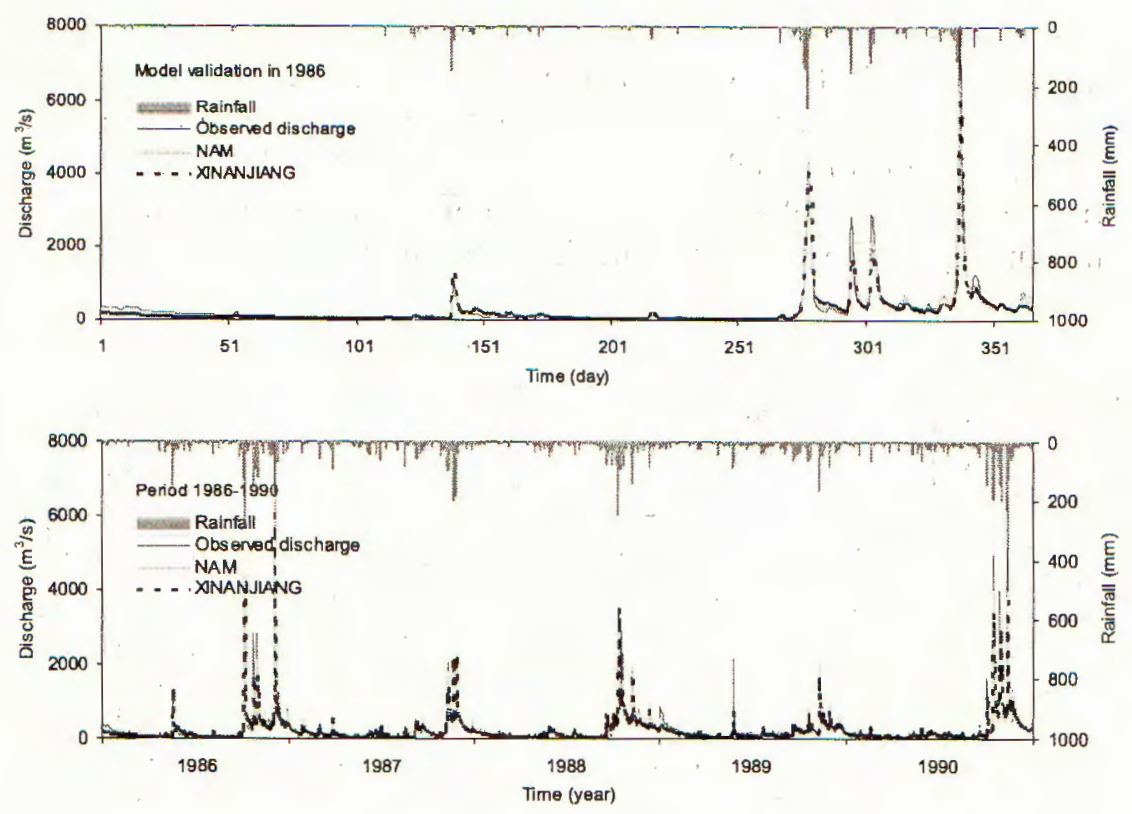

Fig. 6. Model validation results of daily discharges at Nong Son in the 1986-1990 period

interflow and baseflow, there are significant differences between the two models. This difference lies in the ratio of interflow and overland flow; in this case, the simulated baseflow of NAM is much higher than that of XINANJIANG. Based on the statistical results, XINANJIANG calculates $22.1 \%$ and $18.2 \%$ surface runoff, $47.4 \%$ and $48.6 \%$ interflow, $30.5 \%$ and $33.2 \%$ baseflow, whereas NAM calculates surface runoff, interflow and baseflow each with $50.1 \%$ and $48.2 \%$ surface runoff; $3.6 \%$ and $4.3 \%$ interflow; and $46.3 \%$ and $47.5 \%$ baseflow during the calibration and validation periods. Due to lack of investigation data for flow separation in this study area, there is insufficient evidence to determine which model better simulates the portion of flow components. However, based on the result calculated by the method of constant-discharge baseflow separation ( $24 \%$ baseflow in total with a residual value of $\pm 12 \%$ ), and further consideration from the natural conditions influencing the process of flow-formation such as soil, land cover, and climate, the interflow component cannot be smaller than $5 \%$ as that simulated by the NAM model. From this perspective; XINANJIANG, as far as this case study case can determine better a reproduced the distribution into three runoff components. Results are realistic in line with model conceptual principles.

\section{CONCLUSIONS}

The two generalized modeling systems, NAM and XINANJIANG, have been used in this study in a tropical humid zone (Nong Son) with a very high areal rainfall amount, i.e. an average annual value of $3,700 \mathrm{~mm}$. NAM is a typical representative of the lumped conceptual model while XINANJIANG allows for subbasin division.

Overall model performance is impressive. The overall water balance agrees to less than $\pm 10 \%$ during the calibration and validation periods. In all cases, models $R^{2}$ value 
exceeds indicating close agreement between the calculated and observed streamflows at the catchment outlet. This is confirmed by the coefficient of correlation equal to or higher than 0.92 for both NAM and XINANJIANG.

In terms of model comparison, a number of specific conclusions may be derived from the case study. First, with regard to the overall model performance in this application, it is difficult to conclude which model, NAM or XINANJIANG, is better. In this case, the performance statistics of model efficiency and correlation coefficient from NAM is slightly higher than that from XINANJIANG during the calibration and validation period although the XINANJIANG model is considered as a reference model in China

Secondly, with regard to the separation of runoff components, although there was no investigation data for the portion of surface runoff, interflow and baseflow contributed to the discharges. In this study the central objective in the calibration of the models is to obtain the optimal agreement between the predicted and observed discharges at the stream gauges only. XINANJIANG reproduced the distribution of rainfall into the three runoff components well, with interflow as the dominant component. What really happens in the field requires additional investigations to be better disposed to ascertain the individual contributions of each runoff component to the overall discharge.

Hence, it can be proven that there is no universal model which is appropriate for the solution of all hydrological problems as well as for all catchments with different natural conditions; the choice of model to use by the hydrologist depends on the antecedent situation for a particular catchment.

In summary, in the present conditions, if we focus on overall discharges, a lumped model of the NAM type would be a suitable tool from the point of view of technical and economical feasibility. Whereas, in some cases that focus on flow separation, e.g. to determine water underground for irrigation, and other water users then XINANJIANG is expected to give better results. As not all models generated the same behaviour in all investigated catchments, further modeling investigations seem to be required. These studies should focus on a comparison of further models and different model concepts and on varying catchment characteristics, e.g. soils, land use and climate.

\section{ACKNOWLEDGEMENTS}

The supports of Danish Hydraulic Institute (DHI) in providing the NAM license for its application and data by Southern Institute of Water Resources are duly acknowledged. We would like to thank the anonymous reviewers and editors for their pertinent comments, leading to improvements in the paper.

\section{REFERENCES}

1. R.G. Allen, L.S. Pereira, D. Raes and M. Smith, Crop evapotranspiration-Guidelines for computing crop water requirements - FAO Irrigation and Drainge Paper 56, FAO, Rome, 1998.

2. DHI Water \& Environment, MIKE 11, Horsholm, Denmark, 2004a.

3. DHI Water \& Environment, MIKE Basin, Horsholm, Denmark, 2004b.

4. C. Q. Hu, Computational method of runoff generation in semi-humid and semi-arid regions, In: Proc. Symp. on Hydrological Information and Forecasting, China Water Power Press, Beijing, China, 1993, pp. 57-62 (in Chinese). 
5. J. E. Nash and J. V. Sutcliffe, River flow forecasting through conceptual models, Part I: A discussion of principles, Journal of Hydrology 10 (1970) 282-290.

6. Nguyen Ngoc Anh, The Evaluation of Water Resources in the Eastern Nam Bo, Vietnam, Project KC12-05, Sub-Institute for Water Resources Planning, Ho Chi Minh City, 1995 (in Vietnamese).

7. S.A. Nielsen and E. Hansen, Numerical simulation of the rainfall runoff process on a daily basis, Nordic Hydrology 4 (1973) 171-190.

8. SIWRP, Development of GIS Database system for Dong Nai river basin - Technical report, Southern Institute for Water Resources Planning, Ho Chi Minh City, 2004 (in Vietnamese).

9. SIWRR, Study on the integrated water resources management \& utilization of the combined Dau Tieng - Phuoc Hoa system, Southern Institute of Water Resources Research, Ho Chi Minh City, 2004.

10. SIWRR, Study on scientific-technological methodologies to take full advantage of surface water and ground water for crop plants and domestic animals in drought areas of Highland, Southern Institute of Water Resources Research, Ho Chi Minh City, 2006 (in Vietnamese).

11. SWECO International, Song Bung 4 hydropower project, TA No. 4625-VIE, 2006.

12. Tran Thuc, Luong Tuan Anh and Huynh Lan Huong, Flood forecast and inundation computations for the Thu Bon river system, Institute of Meteorology and Hydrology, Ha Noi, Vietnam, 2000.

13. X. Wang, C.T. Mosley, J.R. Frankenberger and E.J. Kladivko, Subsurface drain flow and crop yield predictions for difference drain spacing using DRAINMOD, Agric. Water Mana. 79 (2) (2006) 113-136.

14. C. J. Willmott, Some comments on the evaluation of model performance, Bull. Am. Meteorol. Soc. 63 (1982) 1309-1313.

15. R. J. Zhao, Y. L. Zhuang, L. R. Fang, X. R. Liu, and Q.S. Zhang, The Xinanjiang model, Hydrological Forecasting Proceedings Oxford Symposium, IAHS 129, 1980, pp. 351-356.

16. R.J: Zhao, and X.R. Liu, The XINANJIANG model, In: V. P. Singh (ed.) Computer models of watershed hydrology, Water Res. Publ., Colo., USA, 1995, pp. 215-232.

Received March 10, 2008

\section{SO SÁNH KÊT QUẢ MÔ PHÓNG THUÝ VĂN LUUU VỤC NÔNG SƠN BẰNG HAI MÔ HİNH NAM VÀ XINANJIÁNG}

Nghiên cứu trình bày kết quả mô phơng quá trình dòng chảy cho tiểu vùng Nông Sơn thuộc lưu vực sông Vũ Gia-Thu Bồn, Miền Trung Việt Nam bằng mô hình NAM và XINANJIANG. Kết quá cho thấy cá hai mô hình mô phỏng khá tốt, Iưu lượng tính toán bằng mô hình phù hợp với số liệu thực đo. Sai số tổng lượng dòng cháy nhỏ hơn $10 \%$, hệ số hiệu quá Nash-Sutcliffe $R^{2}$ đạt trền 0.85 , và hệ số quan hệ Pearson $r$ trên 0.92 trong cá thời kỳ hiệu chỉnh và kiềm định mô hình. Mô hình NAM mô phỏng dòng cháy tại trạm đo có phần nào tốt hơn, trong khi XINANJIANG có khả năng tái hiện sự phân bổ ba thành phân dòng chảy gồm dòng mặt, sát mặt và dòng ngầm. 